\title{
CUSTOMER ENGAGEMENT - THE CO CREATION OFVALUE IN THE MARKETING PROCESS
}

\author{
M. Shyja Karunakaran and P.T. Raveendran \\ Department of Management Studies, Kannur University, India
}

\begin{abstract}
The customers' involvement in the process of value creation, his influences in this area, and his efforts at co creation of value, is sought to be grouped under an area christened as Customer Engagement. It has been defined differently by different researchers and a universally accepted definition is yet to be formulated. Evolving from relationship marketing and the service dominant logic, it has grown beyond the traditional concepts of marketing and customer behaviour. Scope of customer engagement is wide and varied and so are its dimensions. The proactive customer is a vast opportunity as well as constant threat. In an India which is young, competitive, consumptive as also extremely connected, customer engagement assumes added significance. This paper makes an attempt to study the different aspects and dimensions of customer engagement.
\end{abstract}

Keywords:

Value Co-Creation, Service Dominant Logic, Relationship Marketing, Customer Experiences, Consumption Value, Online Communities

\section{INTRODUCTION}

In the process of value creation by companies and brands, the customer is no longer an outsider who has to be cajoled and feted to behave in a manner that is beneficial to the marketer. Companies have realized that the customer being made a part of the value creation process leads to an enriching experience for all the stakeholders. The customers' involvement in the process of value creation, his influences in this area, and his efforts at co creation of value, is sought to be grouped under an area christened as Customer Engagement. The proactive customer is significant since his activity and influence is wide and far reaching in this era of constant connectivity. His positive engagement could lead to more loyalty and commitment but his negative engagement in the case of any perceived or otherwise lapse could seriously affect the business.

Customers today, are active contributors to almost all the marketing functions including, product innovation, marketing communication, merchandising, and even acquisition and retention of customers [24][26]. Their activities could be motivated either intrinsically or extrinsically and they could either be guided by the firm or unguided [24]. Customers themselves have become marketers, they often have greater influence, and lower costs, and their reach is sometimes more effective than their firm-based counterparts [20]. The firms have no choice but to take cognizance of this transfer of control to the customer, as this could affect them significantly.

The term Customer Engagement, which had been unheard of in the last decade, has gone from a completely unused term to a topic that raises more than 6 million Google search hits today [10]. In this scenario, businesses are investing substantial resources in an effort to understand and monitor customer engagement and to make it a part of strategic decision making [41]. Companies like Anheuser-Busch is expected to spend more than \$200 billion annually, on engagement marketing strategies, beginning 2017.

\subsection{SCOPE OF CUSTOMER ENGAGEMENT}

It is extremely important for businesses today to understand how the customer experiences the value offered to him, and how he engages himself with the businesses and other stakeholders in order to improve his and their experiences. Organizations are spending millions of dollars in creating enjoyable retail experiences so that consumers can interact physically with their merchandise [2]. Programs are being created to educate consumers and new products are being developed which can be highly personalized for the consumer (e.g. iPod) [42]. Companies are also providing platforms for consumers to interact with oneanother through blogs, feeds, podcasts, and public events. Although most successful businesses realize that mass marketing need to be replaced by creation of unique experiences, and are encouraging consumers to participate and interact with businesses [29], they are not exactly sure about how the consumers can be involved most effectively, and which elements of such efforts can best impact the bottom-line [42].

For a long time, customer retention was considered one of the most important activities of businesses and this excessive focus on retention had led to the neglect of understanding about the acquisition of customers. The service-dominant (S-D) logic [39] [40] and the writings of [30] emphasized the importance of experiences of prospects, potentials, and the value configurationsthe "economic and social actors within networks interacting and exchanging across and through networks" [40].

Customers may be engaged with offerings (e.g. iPod), activities (e.g. Beauty workshops by Clinique), institutions (e.g. Ikea), or brands (e.g. Apple). Customers may be engaged with the offerings or activities of profit-making businesses as well as nonprofit organizations. Engagement might be in the presence or absence of other customers (e.g. creating music on the iPod or interacting with other pregnant moms at baby-birth seminars in hospitals), online or offline (e.g. Apple lovers blogs or Sephora beauty workshops). Customers might also be engaged on the organization's premises (e.g. customized retail experiences) or in places other than the organization premises (e.g. Self-esteem workshops by Dove), in activities organized by the businesses, or by customers themselves. Organizations engage customers directly or through third-parties, as it happens when they are embedded in social networking sites. These contexts of engagement are only indicative of the scope of engagement and are certainly not an exhaustive listing of the possibilities. A listing of these contexts suggest a consumption environment where the customer has transcended from the state of being the subject in 
the society and welcomes opportunities for connecting with objects, events, people, and institutions.

\subsection{RESEARCH GAP}

In spite of all the attention, and a reasonable amount of research into the concept, confusion about the meaning of customer engagement is pervasive. Research on customer engagement itself remains scarce and fragmented. The question therefore still remains, on how firms can strategically guide customer engagement in ways that benefit their own performance.

The term engagement is being used increasingly in the broader academic marketing literature, since 2005. In spite of this increasing use, academic research into the term, how it differs from other similar terms like involvement or participation, and efforts to define it properly have been limited. The Marketing Science Institute (MSI) had listed customer engagement as one of its top most research priorities, and had called for a better understanding of engagement, as far back as 2006. As "rapid changes in communications technology as well as globalization of markets are creating communities of customers and prospects rather than a multitude of isolated customers companies are discovering new ways to create and sustain emotional connection with the brand, thus engaging customers through innovation and design". In 2010, it again prioritized this aspect. Marketing Science Institute, 2010, emphasize the need for further research addressing the consumer/customer engagement concept. In its research priorities for 2014-16, Marketing Science Institute (MSI) had again listed "Understanding Customers and the Customer Experiences" as its top priority.The MSI identifies customer engagement as an important area for research which will contribute to increased academic insight into consumer behaviour in an increasingly complex, interactive and co-creative marketing environment.

\subsection{RESEARCH FRAMEWORK METHODOLOGY}

The framework of study is a conceptual nature. The study seeks to understand the conceptual foundations of the concept of customer engagement and its various dimensions. The study also looks at the theoretical background of the topic and how the area under study has evolved over a period of time since it came into the focus. The data is collected from secondary sources which are academic papers published in this area and from previous studies.

\section{CONCEPTUAL FOUNDATION}

Kahn [19] defined personal engagement as "the simultaneous employment and expression of a person's "preferred-self" in task behaviors that promote connections to work and to others, personal presence (physical, cognitive, and emotional), and active, full role of performance". There are two characteristics of Kahn's [19] definition: (1) Engagement has a psychological connection with the performance of tasks rather than an attitude toward tasks. (2) Engagement concerns the self-investment of personal resources in a task, specifically with an investment of multiple dimensions (physical, emotional, and cognitive) of the self (Christian et al. 2011).
The conceptual foundation of customer engagement stands on the theory of consumption values, the consumer value perspective, and the existing literature on engagement and customer engagement [42]. Researches in the past decade have shown that value is not just economic [11] or functional, but also emotional, epistemic, conditional [35], social [35] [11], hedonic and altruistic [11]. Recent developments in marketing suggest that "value is always uniquely and phenomenologically determined by the beneficiary" [40] and that "consumer choice is a function of multiple consumption values" [35]. Recent researches therefore have proved that the meaning of value and the process of value creation have undergone vast changes. The exchange or transaction centric view is no longer considered optimal. Businesses are seeking ways to provide personalized consumer experiences.

The concept of customer engagement is an emerging one in marketing literature. The key objects of customer engagement cited in existing marketing literature are brands, products and organizations [28] and brand communities [1]. In the last decade, there have been many marketing studies with constructs carrying the "engagement" label. However, the definitions, dimensionality, and operationalizations of the customer engagement construct have not been very consistent.

Bowden [3] saw customer engagement as a psychological process that leads to the formation of loyalty. According to Van Doorn et al. [38] customer engagement is "the behavioral manifestation from a customer toward a brand or a firm which goes beyond purchase behavior". Patterson et al. [28] definition of customer engagement was based on many parent disciplines like psychology and organizational behavior; and defined it as a psychological state characterized by vigor, dedication, absorption, and interaction.

Customer engagement is most often situated, in the larger context of service management approach [8] and within the relationship marketing paradigm. The relationship marketing paradigm emphasizes the importance of customer orientation and customer partnering, relationships orientation [8], and interaction between customers and brands. The service management approach focuses on customers' active role in value co-creation, as it is defined in the service-dominant logic research [40] [30]. Today, social media has enhanced interactions among customers and brands and are providing new possibilities for customers' empowerment and activities. Therefore customer engagement is being nowadays increasingly investigated in the online context [9] [27]. Other situations of marketing communication, such as loyalty programs [3] or events [45] are also being investigated.

Customer engagement has been conceptualized essentially as a multidimensional construct by most researchers [3] [5] [12] [25] taking into consideration cognitive, emotional and behavioral dimensions. Existing literature has strongly tended towards a multi-dimensional form for customer engagement construct. Van Doorn et al. [38] who proposed customer engagement behavior as a unidimensional construct focusing on behavioral aspect (Fig.1), was the major exception. Calder et al. [5] proposed that customer engagement happens only when the customer experiences a particular interaction in a certain way. They defined an experience as a consumer's beliefs about how a medium fits into his/her life [5]. Customer experiences are dependent mostly on the customer's motivations for interactions with the focal object 
which could be the medium, or the service or the brand. Experiences could be said to precede engagement, where they are first-order constructs while engagement is a second-order construct [5].

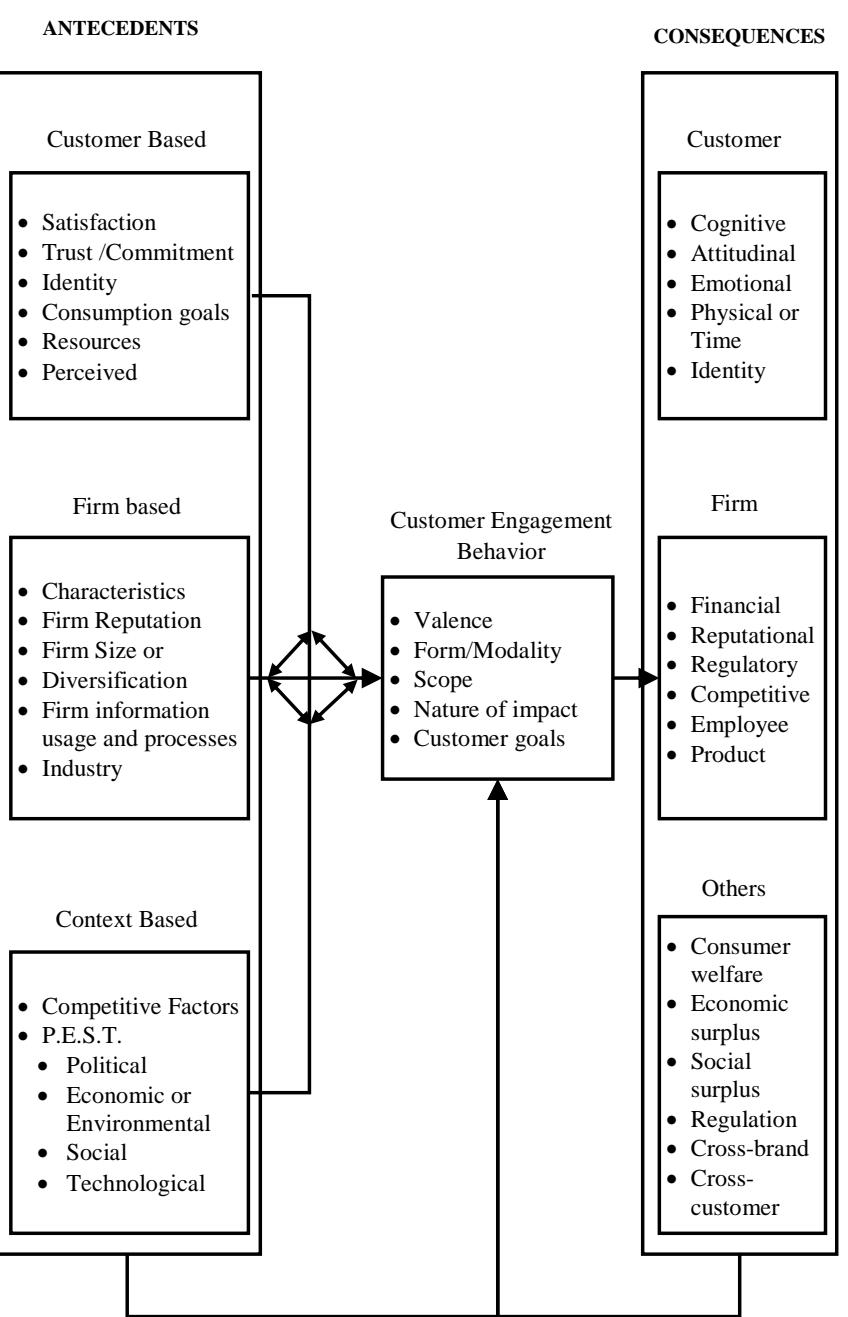

Fig.1. Van Doorn's Conceptual Model of customer engagement behavior

Source: van Doorn et al. [38]

\section{THEORETICAL FRAMEWORK}

The theoretical basis of customer engagement concept is the theory of relationship marketing. Vivek et al. [33] refers to it as the "expanded domain of relationship marketing." The relationship marketing theory is the wider conceptual lens through which customer engagement is to be examined. "A transcending view of relationships," from a service-dominant (S-D) logic perspective, which sharply contrasts with the more traditional view of marketing relationships which is a "goods-dominant" (GD) perspective. This relational perspective, which is broad and "transcending" recognizes that consumer behaviour is based on customers' and/or other stakeholders' interactive experiences taking place in complex and co-creative environments. Vivek et al. [33] elaborate on the "expanded domain of relationship marketing" by drawing on [43], [30], [39], [40] research. Firms focus on existing and prospective customers, as well as consumer communities and their organizational value co-creative networks within the broad relationship marketing domain. According to Vivek et al. [33] consumer engagement is a central concept within the marketing system. Lusch and Vargo [22] suggest that these interactive consumer experiences co-created with other actors can be interpreted as the act of "engaging".

\section{VARYING BASES CONCEPTUALISATION}

Customer engagement has been conceptualized in different ways by different researchers. Some see it as behavioral, others as psychological [13] [15]. The larger consensus exists on the fact that it is a customer's behavioral response to a firm, which goes beyond the usual responses that are part of the core economic transaction [38]. To be more specific, it includes activities engaged in by the consumer that are not directly related to search, alternative evaluation, and decision making involving brand choice [33]. Even researchers who chose to believe in the psychological perspective emphasize its interactive nature, and assert that customers choose to invest resources in particular brand interactions, thus, implying a behavioral component [14] [4]. Though it is preferably defined behaviorally rather than psychologically, one should not lose sight of the fact that the psychological constructs like involvement, satisfaction, brand love, cognitive, and affective commitment are also extremely relevant to the construct.

In such case these psychological constructs are allowed to fluctuate independently, and have unique antecedents and consequences, and they relate to customer engagement as either an antecedent or an outcome [21]. Taking customer engagement behaviors outside the core transaction behaviors, clearly distinguishes the concept from behavioral loyalty (i.e., repeat purchases) and other transaction-focused behaviors that are frequently studied in marketing. On the negative side, the disadvantage of giving importance only to those activities beyond purchase is that it results in trivializing a wide variety of other customer behaviors e.g., product returns, product usage, product disposal, brand learning etc. Thus, retaining surplus meaning on one hand could lead to dilution of the effectiveness of the term.

\section{ORGANIZATIONAL VARIABLES AFFECTING CUSTOMER ENGAGEMENT}

The extent to which the customers can be engaged is dependent on various factors like organizational processes, enabling technologies, goal alignment of the organization with the customers, monitoring processes in organizations, and most importantly, the different roles customers want to take [6] [26]. Customers are being engaged by businesses mainly in the product development life-cycles, and they are also being involved into product and process innovations [44] [18] [26] [37]. The Table.1 indicates the organizational functions affected by customer engagement. 
Table.1. What is customer engagement? Implicit and explicit perspectives

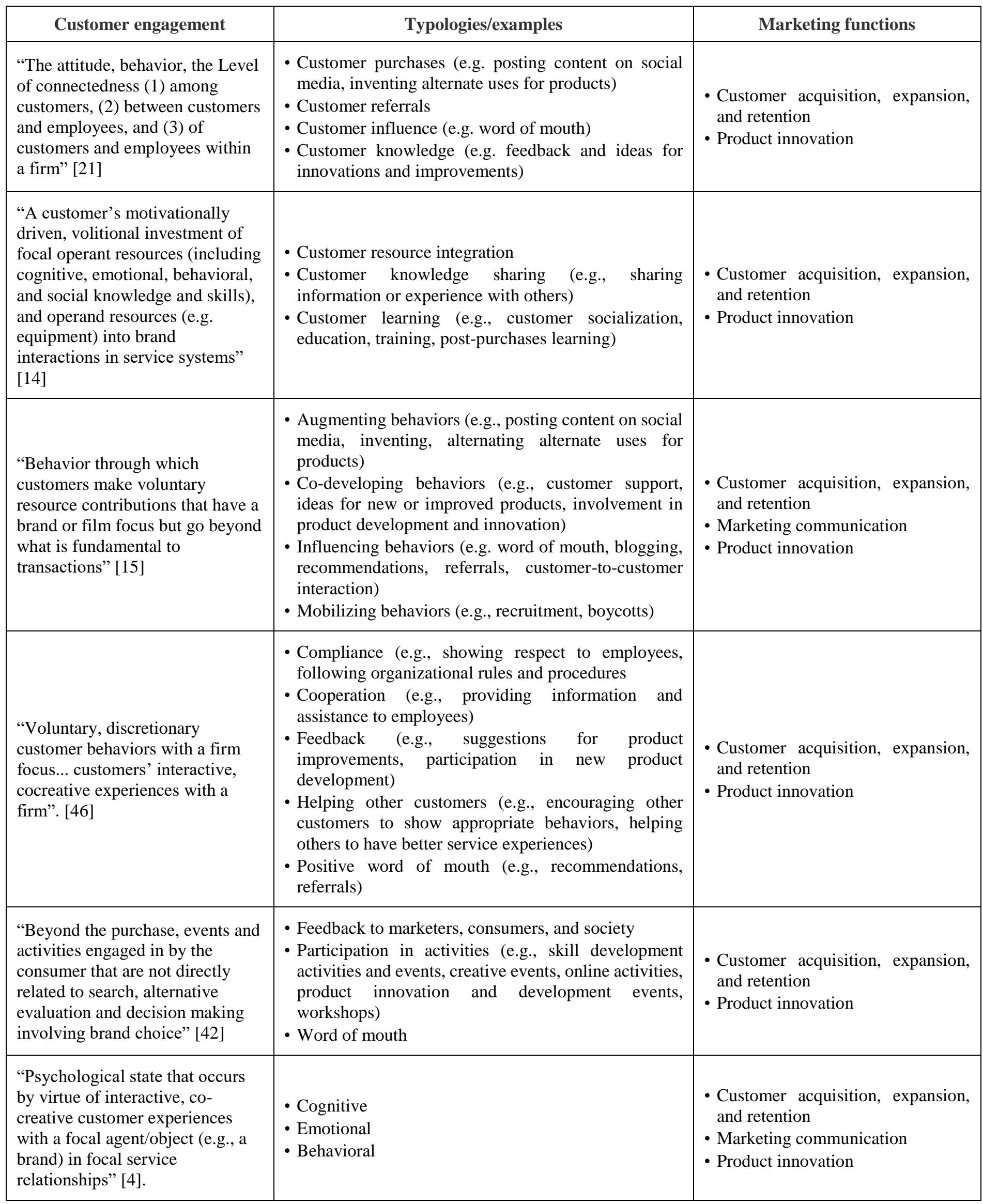




\begin{tabular}{|c|c|c|}
\hline $\begin{array}{l}\text { "The level of an individual } \\
\text { customer's motivational, brand- } \\
\text { related and context-dependent } \\
\text { state of mind characterized by } \\
\text { specific levels of cognitive, } \\
\text { emotional and behavioral activity } \\
\text { in direct brand interactions" [12] }\end{array}$ & $\begin{array}{l}\text { - Cognitive activity (e.g., level of concentration and /or } \\
\text { engrossment in the brand) } \\
\text { - Emotional activity (e.g., level of brand-related } \\
\text { inspiration and/or pride) } \\
\text { - Behavioral activity (e.g., level of energy exerted in } \\
\text { interacting with a focal brand) }\end{array}$ & $\begin{array}{l}\text { - Customer acquisition, expansion, } \\
\text { and retention } \\
\text { - Marketing communication }\end{array}$ \\
\hline $\begin{array}{l}\text { "Customers contribute to firms in } \\
\text { many ways that are beyond direct } \\
\text { transactions." [31] }\end{array}$ & $\begin{array}{l}\text { - Customer influencer behavior (e.g., word of mouth) } \\
\text { - Customer knowledge behavior (e.g., feedback and } \\
\text { ideas for innovations and improvements) } \\
\text { - Customer referral behavior (e.g., referrals) }\end{array}$ & $\begin{array}{l}\text { - Customer acquisition, expansion, } \\
\text { and retention } \\
\text { - Product innovation }\end{array}$ \\
\hline $\begin{array}{l}\text { "Customer behavioral } \\
\text { manifestations toward the brand } \\
\text { or firm, beyond purchase" [38] }\end{array}$ & $\begin{array}{l}\text { - Blogging, web posting } \\
\text { - Customer-to-customer interaction } \\
\text { - Feedback, suggestions for new products ideas } \\
\text { - Organizing public actions against a firm } \\
\text { - Recommendations, referrals, word of mouth } \\
\text { - Writing reviews }\end{array}$ & $\begin{array}{l}\text { - Customer acquisition, expansion, } \\
\text { and retention } \\
\text { - Marketing communication } \\
\text { - Product innovation }\end{array}$ \\
\hline $\begin{array}{l}\text { "A behavioral manifestation } \\
\text { toward the brand or firm that goes } \\
\text { beyond transactions" [41] }\end{array}$ & $\begin{array}{l}\text { - Blogging } \\
\text { - Co-creation with new product development activity } \\
\text { - Providing customer ratings } \\
\text { - Customer-to-customer interactions (i.e., word of } \\
\text { mouth) }\end{array}$ & \\
\hline
\end{tabular}

Source: Harmeling et al., [10]

\section{DIMENSIONS ENGAGEMENT}

Some of the earliest researchers of the concept of customer engagement, Brodie et al. [4] had categorized customer engagement as multidimensional and identified the dimensions as behavioral, emotional and cognitive. These dimensions or a combination of them remained the core ones in most of the studies published between 2009 and 2012. Javornik et al. [17] proposed a modified categorization of the customer engagement research streams which differed slightly from the earlier studies. Their study differed on three main points: the first, as the behavioral perspective defined by Van Doorn et al. [38] has become so largely accepted, it should be recognized as a separate research stream. The behavioral customer engagement underscores the importance of the customer's active role which makes the whole concept of engagement so relevant in the marketing process [38].

Javornik et al. [17] also proposed to unite the cognitive and affective (emotional) perspective into one research stream, the psychological customer engagement. They believed that both the cognitive well as emotional studies focus on the psychological processes that are antecedents to the act of customer engagement. So, instead of separating the emotional and cognitive dimensions, it is important to recognize which of the processes take place on the psychological level prior to behavioral engagement. Majority of customer engagement literature has so far focused on the phenomenon on an individual level and as a relationship between the customer and organization. The social customer engagement, as they are observed in the online communities, social networks and other $\mathrm{C} 2 \mathrm{C}$ media has now come to the forefront and need to be paid attention to [7] [9].

The dimensions of customer engagement are thus many fold. The behavioral perspective is concerned with the behavioral aspects of customer engagement and the customers' activities, mostly extending beyond the economic transaction. Behavioral perspective investigates consumers' activities, such as word-ofmouth, recommendations, repeat purchases, social media activities, community participation, interactions with brands and such similar activities [34] [9] [16]. Such approach is often favoured by practitioners as it can lead to quantification and measurement of consumers' activities in their interactions with brands.

The psychological-cognitive and affective-perspective investigates the customers' cognitive and affective processes which precede engagement or an interaction with brands. This stream tackles engagement from various psychological, mainly affective or cognitive, angles. The studies on this perspective provide researchers with valuable insight into what motivational triggers lead to the consumers' attention, cognition and affection. 
According to some authors, engagement is the basis of the consumer experience with a media or with a brand which could occur through marketing or any type of marketing communication [5] [27]. Calder et al. [5] defined that engagement is established through user's experience with the media and the behaviors are thus a representation of only the consequences of the engagement and are not indicators of it. Mollen and Wilson [25] suggested that customer's tele presence and sustained attention is also a part of the engagement process. Many studies which showed that different levels of interactivity influence the process of engagement are especially relevant in the online environment [25] [27]. Studies by Calder et al. [5] showed that engagement with online media is affected by new motivational factors which are different to some extent from those factors which lead to engagement with traditional media. In the online media, the social and interactive components become crucial, and this was further confirmed by study of Pagani and Mirabello [27]. In view of all the studies above, Javornik et al. [17] proposed a separate psychological approach to customer engagement.

The multidimensional perspective unifies the different dimensions of customer engagement and proposes a multidimensional approach. Many attempts have been made to unify different levels of customer engagement [25] [34] [32] [33] [7]. Multidimensional approach to customer engagement aims to bridge the customer's and firm's perspective by applying the conceptualization within the larger context of value cocreation and customer's active role in it. Studies within this research stream often focus on linking the cognitive and affective triggers with engaging behaviors [25] and [34] [4] [33]. Brodie et al. [4] provide also a complex and all-encompassing conceptualization of customer engagement. While this highly theoretical definition points out the contribution of the concept, it does not succeed in distinguishing different approaches to the study of the phenomenon. Furthermore, Mollen and Wilson [25] show that there has been limited empirical academic literature that would prove direct correlation between online engagement and behavioral manifestations.

The social perspective which takes into account the social and network component of the phenomenon is also an important dimension. Even though the majority of the initial studies on customer engagement focused on the individual aspects, there has also been a recent emergence of studies that investigate social dimensions of the phenomenon [7] [23]. Through their analysis of the marketing debate, Gambetti et al. [7] emphasized the complex nature of customer engagement. They showed that it is influenced by many different components and that it changes character according to different contexts due to its postmodern character. Gambetti et al. [7] believed that customer engagement should be approached with qualitative studies which would better capture its multi-faceted reality on a social level. A complex and critical analysis by Mandelli and Accoto [23] emphasized that the process of engagement is strongly linked to the process of interactions. These processes consisted of negotiated meanings which are always integral to the socio-cultural context of the relationship. Mandelli and Accoto [23] follow Gronroos [8] approach to value concretion conceptualization; emphasizing the fact that applying a direct link between customer engagement and value co-creation oversimplifies the issue. The phenomenological and socio-cultural layers of the interaction between brands and customers need to be taken into account. It has also to be taken into account that the value of interactions and experience for customers do not come merely by being engaged but from the value of these experiences as well.

\section{MANIFESTATIONS OF CUSTOMER ENGAGEMENT}

Customer engagement has been recognized as an emotional connection between a company and its customers. Customer engagement is also focused on interaction with and participation of customers [26]. Exchange of knowledge with and among the customers are best ways to engaging customers. The blossoming of information and communication technologies and their wide use by companies as well as customers are providing great opportunities for organizations to exchange knowledge and engage with the customer [6] [18].

Provider initiated vs. customer initiated engagement: Customer engagement could be provider-initiated engagement or customer initiated. Similarly, the foci of engagement could be offerings and activities. Engagement with offerings in this type results from the interactivity of the offering that allows the customer to play an active role in creating a unique experience, or getting nonfunctional value. Vivek [42] identifies products from Apple, specifically the iPod, iPhone and the apple computer as products that allow their owners to create and share their own experiences combining different technologies. Not only high-technology products, but simpler gadgets like digital video recorders (DVRs), TiVo, and cell phones, even knitting needles and sewing machines are very engaging for the customer because of their ability to let the customer work on their imagination and meet their individual needs [42].

Activities initiated by businesses include engagement behaviors that are focused on programs, events or activities that are not directly related to the offerings of the businesses that initiate them. In an attempt to have one-on-one interactions with customers and to develop better long-term relationships with customers, the leading organizations invite customers to participate at different stages in product development, distribution and sales. Companies like Microsoft have been inviting customers to participate in creating their new products. A decade ago Whirlpool urged housewives to design an ideal refrigerator for them. Direct marketing businesses such as Tupperware and Avon host parties for customers where their products are indirectly promoted through use. Such "experiential in-home marketing events" are no more an exclusive tool being used by direct marketing companies. Even traditional marketing companies like NBC, Ford, Gerber and Hershey's are using such events to engage customers.

Offerings initiated by the customers are the flea markets in the U.S. and in European cities which engage a very large number of customers week after week. A similar engagement also occurs with yard sales, garage sales and thrift stores. People look forward to these sales organized by other customers, not only for buying and selling but also for the emotional connect it provides them with similar minded individuals.

Activities initiated by the customers themselves include hobbies that use some product, service or organization. The most cited example in this category is that of shopping and window shopping. The next set of examples includes several hobbies like 
photography, gardening, and fishing. All of these activities are designed as well as initiated by the customers themselves, although the initiation of and participation in these activities are supported by offerings from organized businesses.

\section{DISCUSSION}

The purpose of this paper was to delve deeper into an area which is attaining all-consuming importance to businesses whether for profit or nonprofit, and to society at large. The paper aims to generate interest in this area which is crucial for success of businesses, customers and all other stakeholders involved in the economic activity of producing, selling and buying. The process has evolved from the service-dominant (S-D) logic and the increased importance of experiences of prospective and potential customers, and their value configurations. The theoretical basis of customer engagement concept is the theory of relationship marketing. The engagement behavior of customers has wide ramifications. It is a not easy to unravel as it involves the psychological, social, cultural and various environmental factors that affect the customer. The various perspectives of customer engagement include behavioral, psychological, social and interactive as well as multidimensional. The engagement activity may take place at various levels and in varied environments. Research has shown that it is influenced by many different components and that it changes character according to different contexts due to its postmodern character.

Many of the engagement activities could happen beyond the purview of the organizations whose products and brands are involved in the process. In this era of complete connectivity and booming online activity, the proactive customer is a vast opportunity as well as a constantly looming threat. In present day India, the median age of the population is tending to be around 27 years and there is heightened consumption activity. The majority of the population therefore is highly socially and commercially active digitally. Combined with the politico-socio-economic environment which encourages electronic and digital transactions, the market place is a veritable landmine. Therefore the scope for further research in this area is extremely wide and it is also an urgent necessity. Researchers may choose to focus on any of the aspects of Customer Engagement in order to better understand the concept and throw more light upon it.

\section{CONCLUSION}

As is evident from the above discussion, Customer Engagement is a vast and varied topic which has many dimensions to it. In spite of the fact that it has important ramifications for all concerned in business activities, studies in this area are extremely limited, especially in this part of the world. The scope of this paper is limited and it is constrained by the fact that the framework of the study is mainly at the conceptual and theoretical level. The paper, we believe, has however been successful in highlighting all the important parameters of the subject and it is hoped that it will lead to heightened interest in this area.

\section{REFERENCES}

[1] R. Algesheimer, U.M. Dholakia and A. Herrmann, "the Social Influence of Brand Community: Evidence from European Car Clubs", Journal of Marketing, Vol. 69, No. 3, pp. 19-34, 2005.

[2] S. Baron, K. Harris and R. Harris, "Retail Theater: The "Intended Effect" of the Performance", Journal of Service Research, Vol. 4, No. 2, pp. 102-117, 2001.

[3] J.L.H. Bowden, "The Process of Customer Engagement: A Conceptual Framework", Journal of Marketing Theory and Practice, Vol. 17, No. 1, pp. 63-74, 2009.

[4] R.J. Brodie, L.D. Hollebeek, B. Juric and A. Ilic, "Customer Engagement: Conceptual Domain, Fundamental Propositions, and Implications for Research", Journal of Service Research, Vol. 14, No. 3, pp. 252-271, 2011.

[5] B.J. Calder, E.C. Malthouse and U. Schaedel, "An Experimental Study of the Relationship between Online Engagement and Advertising Effectiveness", Journal of Interactive Marketing, Vol. 23, No. 4, pp. 321-331, 2009.

[6] P. Erat, K.C. Desouza, A. Schafer-Jugel and M. Kurzawa, "Business Customer Communities and Knowledge sharing: Exploratory Study of Critical Issues", European Journal of Information Systems, Vol. 15, No. 5, pp. 511-524, 2006.

[7] R.C. Gambetti, G. Graffigna and S. Biraghi, "The Grounded Theory Approach to Consumer-Brand Engagement", International Journal of Market Research, Vol. 54, No. 5, pp. 659-687, 2012.

[8] C. Gronroos, "Service Management and Marketing: Customer Management in Service Competition", John Wiley and Sons, 2007.

[9] J. Gummerus, V. Liljander, E. Weman and M. Pihlstrom, "Customer Engagement in a Facebook Brand Community", Management Research Review, Vol. 35, No. 9, pp. 857-877, 2012.

[10] C.M. Harmeling, J.W. Moffett, M.J. Arnold and B.D. Carlson, "Toward a Theory of Customer Engagement Marketing", Journal of the Academy of Marketing Science, Vol. 45, No. 3, pp. 312-355, 2017.

[11] M.B. Holbrook, "Consumption Experience, Customer Value, and Subjective Personal Introspection: An Illustrative Photographic Essay", Journal of Business Research, Vol. 59, No. 6, pp. 714-725, 2006.

[12] L. Hollebeek, "Exploring Customer Brand Engagement: Definition and Themes", Journal of Strategic Marketing, Vol. 19, No. 7, pp. 555-573, 2011.

[13] L.D. Hollebeek, "Demystifying Customer Brand Engagement: Exploring the Loyalty Nexus", Journal of Marketing Management, Vol. 27, No. 7-8, pp. 785-807, 2011.

[14] L.D. Hollebeek et al., "Epilogue to the Special Issue and Reflections on the Future of Engagement Research", Journal of Marketing Management, Vol. 32, No. 5-6, pp. 586-594, 2016.

[15] E. Jaakkola and M. Alexander, "The Role of Customer Engagement Behavior in Value Co-Creation: A Service System Perspective", Journal of Service Research, Vol. 17, No. 3, pp. 247-261, 2014.

[16] A. Javornik and A. Mandelli, "Behavioral Perspectives of Customer Engagement: An Exploratory Study of customer 
Engagement with Three Swiss FMCG Brands", Journal of Database Marketing and Customer Strategy Management, Vol. 19, No. 4, pp. 300-310, 2012.

[17] A. Javornik and A. Mandelli, "Research Categories in Studying Customer Engagement", Proceedings of International Conference on Academy of Marketing, pp. 14, 2013.

[18] A.W. Joshi and S. Sharma, "Customer Knowledge Development: Antecedents and Impact on New Product Performance", Journal of Marketing, Vol. 68, No. 4, pp. 47 59, 2004.

[19] W.A. Kahn, "Psychological Conditions of Personal Engagement and Disengagement at Work", Academy of Management Journal, Vol. 33, No. 4, pp. 692-724, 1990.

[20] R.V. Kozinets, K. De Valck, A.C. Wojnicki and S.J. Wilner, "Networked Narratives: Understanding Word-of-Mouth Marketing in Online Communities", Journal of Marketing, Vol. 74, No. 2, pp. 71-89, 2010.

[21] V. Kumar and A. Pansari, "Competitive Advantage through Engagement”, Journal of Marketing Research, Vol. 53, No. 4, pp. 497-514, 2016.

[22] R.F. Lusch, S.L. Vargo and M. Tanniru, "Service, Value Networks and Learning", Journal of the Academy of Marketing Science, Vol. 38, No. 1, pp. 19-31, 2010.

[23] A. Mandelli and C. Accoto, "Social Mobile Marketing", EGEA Publication, 2012.

[24] R.D. Mersey, E.C. Malthouse and B.J. Calder, "Focusing on the Reader: Engagement Trumps Satisfaction", Journalism and Mass Communication Quarterly, Vol. 89, No. 4, pp. 695-709, 2012.

[25] A. Mollen and H. Wilson, "Engagement, Telepresence and Interactivity in Online Consumer Experience: Reconciling Scholastic and Managerial Perspectives", Journal of Business Research, Vol. 63, No. 9, pp. 919-925, 2010.

[26] S. Nambisan, "Designing Virtual Customer Environments for New Product Development: Toward a Theory", Academy of Management Review, Vol. 27, No. 3, pp. 392-413, 2002.

[27] M. Pagani and A. Mirabello, "The Influence of Personal and Social-Interactive Engagement in Social TV Web Sites", International Journal of Electronic Commerce, Vol. 16, No. 2, pp. 41-68, 2011.

[28] P. Patterson, T. Yu and K. De Ruyter, "Understanding Customer Engagement in Services", Proceedings of International Conference on Advancing Theory, Maintaining Relevance, pp. 4-6, 2006.

[29] C.K. Prahalad, "The Blinders of Dominant Logic" Long Range Planning, Vol. 37, No. 2, pp. 171-179, 2004.

[30] C.K. Prahalad and V. Ramaswamy, "Co-creating Unique Value with Customers", Strategy and Leadership, Vol. 32, No. 3, pp. 4-9, 2004.

[31] K. Verleye, P. Gemmel and D. Rangarajan, "Managing Engagement Behaviors in a Network of Customers and
Stakeholders Evidence from the Nursing Home Sector", Journal of Service Research, Vol. 17, No. 1, pp. 68-84, 2013.

[32] Roderick J. Brodie, Linda D. Hollebeek, BiljanaJuric and Ana Ilic, "Customer Engagement: Conceptual Domain, Fundamental Propositions, and Implications for Research", Journal of Service Research, Vol. 14, No. 3, pp. 21-26, 2011.

[33] S.D. Vivek, S.E. Beatty and R.M. Morgan, "Customer Engagement: Exploring Customer Relationships beyond Purchase", Journal of Marketing Theory, Vol. 20, No. 2, pp. 122-146, 2012.

[34] C.M. Sashi, "Customer Engagement, Buyer-Seller Relationships, and Social Media", Management Decision, Vol. 50, No. 2, pp. 253-272, 2012.

[35] J.N. Sheth, B.I. Newman and B.L. Gross, "Why We Buy what we Buy: A Theory of Consumption Values", Journal of Business Research, Vol. 22, No. 2, pp. 159-170, 1991.

[36] T.H.A. Bijmolt, P.S.H. Leeflang and F. Block, "Analytics for Customer Engagement", Journal of Service Research, Vol. 13, No. 3, pp. 112-116, 2010.

[37] S. Thomke and Von Hippel, "Innovators", Harvard Business Review, Vol. 8, No. 4, pp. 74-81, 2002.

[38] J. Van Doorn et al., "Customer Engagement Behavior: Theoretical Foundations and Research Directions", Journal of Service Research, Vol. 13, No. 3, pp. 253-266, 2010.

[39] S.L. Vargo and R.F. Lusch, "Evolving to A New Dominant Logic for Marketing", Journal of Marketing, Vol. 68, No. 1, pp. 1-17, 2004.

[40] S.L. Vargo and R.F. Lusch, "Service-Dominant Logic: Continuing the Evolution", Journal of the Academy of Marketing Science, Vol. 36, No. 1, pp. 1-10, 2008.

[41] P.C. Verhoef, W.J. Reinartz and M. Krafft, "Customer Engagement as A New Perspective in Customer Management", Journal of Service Research, Vol. 13, No. 3, pp. 247-252, 2010.

[42] S.D. Vivek, "A Scale of Consumer Engagement", PhD Dissertation, Department of Management and Marketing, The University of Alabama, 2009.

[43] Eric Von Hippel, "Democratizing Innovation: The Evolving Phenomenon of User Innovation", Journal fur Betriebswirtschaft, Vol. 55, No. 1, pp. 63-78, 2005.

[44] S. Whelan and M. Wohlfeil, "Communicating Brands through Engagement with 'Lived' Experiences”, Journal of Brand Management, Vol. 13, No 4-5, pp. 313-329, 2006.

[45] V. Kumar et al., "Undervalued or Overvalued Customers: Capturing Total Customer Engagement Value", Journal of Service Research, Vol. 13, No. 3, pp. 297-310, 2010.

[46] R.M. Morgan and S.D. Hunt, "The Commitment-Trust Theory of Relationship Marketing”, Journal of Marketing, Vol. 58, No. 3, pp. 20-38, 1994. 